\title{
THE
}

\section{Inhibition of multi-drug resistant HIV-1 reverse transcriptase by nucleoside $\boldsymbol{\beta}$-triphosphates}

\author{
Chandravanu Dash \\ Yousef Ahmadibeni \\ University of Rhode Island \\ Michael J. Hanley \\ Jui Pandhare \\ Mathias Gotte
}

See next page for additional authors

Follow this and additional works at: https://digitalcommons.uri.edu/bps_facpubs

This is a pre-publication author manuscript of the final, published article.

Creative Commons License

c) (i) (9)

This work is licensed under a Creative Commons Attribution-Noncommercial-No Derivative Works 4.0 License.

\section{Citation/Publisher Attribution}

Dash, C., Ahmadibeni, Y., Hanley, M. J., Pandhare, J., Gotte, M., Le Grice, S. F.J., \& Parang, K. (2011). Inhibition of multi-drug resistant HIV-1 reverse transcriptase by nucleoside $\beta$-triphosphates. Bioorganic \& Medicinal Chemistry Letters, 21(12), 3519-3522. doi: 10.1016/j.bmcl.2011.05.005

Available at: https://doi.org/10.1016/j.bmcl.2011.05.005

This Article is brought to you for free and open access by the Biomedical and Pharmaceutical Sciences at DigitalCommons@URI. It has been accepted for inclusion in Biomedical and Pharmaceutical Sciences Faculty Publications by an authorized administrator of DigitalCommons@URI. For more information, please contact digitalcommons-group@uri.edu. 


\section{Authors}

Chandravanu Dash, Yousef Ahmadibeni, Michael J. Hanley, Jui Pandhare, Mathias Gotte, Stuart F.J. Le Grice, and Keykavous Parang 


\title{
Inhibition of multi-drug resistant HIV-1 reverse transcriptase by nucleoside $\beta$-triphosphates
}

\author{
Chandravanu Dash ${ }^{\mathrm{a}}$, Yousef Ahmadibeni ${ }^{\mathrm{b}, \mathrm{c}}$, Michael J. Hanley ${ }^{\mathrm{c}}$, Jui Pandhare ${ }^{\mathrm{a}}$, Mathias \\ Gotte $^{d}$, Stuart F.J. Le Grice ${ }^{\mathrm{e}}$, and Keykavous Parang ${ }^{\mathrm{c}}$ \\ ${ }^{a}$ Center for AIDS Health Disparities Research, Department of Biochemistry and Cancer Biology, \\ Meharry Medical College, Nashville, TN 37208 USA \\ bDepartment of Chemistry, Columbus State University, Columbus, GA 31907 USA \\ 'Department of Biomedical and Pharmaceutical Sciences, University of Rhode Island, Kingston, \\ RI 02881 USA \\ dDepartment of Microbiology and Immunology, McGill University, Montreal, Quebec, Canada H3A \\ $2 \mathrm{T5}$
}

eResistance Mechanisms Laboratory, HIV Drug Resistance Program, National Cancer Institute at Frederick, Frederick, MD 21702, USA

\begin{abstract}
Despite the success of potent reverse transcriptase (RT) inhibitors against human immunodeficiency virus type 1 (HIV-1) in combination regimens, the development of drug resistant RTs constitutes a major hurdle for the long-term efficacy of current antiretroviral therapy. Nucleoside $\beta$-triphosphate analogs of adenosine and nucleoside reverse transcriptase inhibitors (NRTIs) (3'-azido-2',3'-dideoxythymidine (AZT), 3'-fluoro-2', 3'-dideoxythymidine (FLT), and 2', $3^{\prime}$-didehydro-2', $3^{\prime}$-dideoxythymidine (d4T)) were synthesized and their inhibitory activities were evaluated against wild-type and multidrug resistant HIV-1 RTs. Adenosine $\beta$-triphosphate (1) and AZT $\beta$-triphosphate (2) completely inhibited the DNA polymerase activity of wild type, the NRTI multi resistant, and non-nucleoside RT inhibitors (NNRTI) resistant HIV-1 RT at $10 \mathrm{nM}, 10 \mu \mathrm{M}$, and $100 \mu \mathrm{M}$, respectively.
\end{abstract}

\begin{abstract}
During HIV-1 replication, the viral RNA genome is reverse transcribed into an integrated competent double stranded DNA by the virally encoded multifunctional enzyme reverse transcriptase (RT). ${ }^{1}$ HIV-1 RT remains a prime target for continued development of antagonists to inhibit virus replication and stem the devastating consequences of AIDS. HIV-1 RT is a heterodimeric enzyme composed of 66 and $51 \mathrm{kD}$ subunits (p66 and $\mathrm{p} 51$ ) possessing RNA- and DNA-dependent DNA polymerase and RNase $\mathrm{H}$ activities. ${ }^{2}$ DNA polymerase activity is essential for the synthesis of a RNA:DNA heteroduplex from the single stranded viral RNA genome. RNase $\mathrm{H}$ hydrolyzes the RNA strand of the RNA:DNA heteroduplex generated during reverse transcription and creates the primer for plus strand
\end{abstract}

(C) 2011 Elsevier Ltd. All rights reserved.

Correspondence to: Keykavous Parang.

Supplemental Data including experimental procedures and characterization of compounds can be found in the online version of this article.

Publisher's Disclaimer: This is a PDF file of an unedited manuscript that has been accepted for publication. As a service to our customers we are providing this early version of the manuscript. The manuscript will undergo copyediting, typesetting, and review of the resulting proof before it is published in its final citable form. Please note that during the production process errors may be discovered which could affect the content, and all legal disclaimers that apply to the journal pertain. 
DNA synthesis. Thus, both DNA polymerase and RNase $\mathrm{H}$ activities of HIV-1 RT have been considered as potential targets for antiretroviral therapy. ${ }^{3}$

Two classes of drugs belonging either to the nucleoside/nucleotide reverse transcriptase inhibitors (NRTIs) or to the non-nucleoside reverse transcriptase inhibitors (NNRTIs) have been used in the clinic as part of the antiretroviral therapy against HIV/AIDS. ${ }^{4}$ NRTIs compete with the natural deoxynucleoside triphosphates (dNTPs) during DNA synthesis and act as chain terminators. ${ }^{5}$ In contrast, NNRTIs are non-competitive inhibitors that bind at an allosteric nonsubstrate binding site, which is distinct from the substrate binding site of HIV-1 RT. ${ }^{6}$ While the unique pharmacology of these inhibitors has rendered their use in highly active antiretroviral therapy (HAART) therapy, HIV-1 has the ability to develop drug resistance mutations for both NRTI and NNRTIs. ${ }^{7}$ Thus, design of novel lead compounds that can inhibit wild-type and drug resistant HIV-1 RTs is a subject of major interest in antiviral research.

Modified nucleoside triphosphates that mimic naturally occurring deoxyribo- and ribonucleoside triphosphates have been used as probes in several biochemical pathways involving DNA and RNA synthesis, and as potential diagnostic and therapeutic agents. ${ }^{8,9}$ The structural similarity of modified nucleotides to natural deoxyribo- and ribonucleoside triphosphates makes them useful reagents as substrates or inhibitors for DNA or RNA polymerases. ${ }^{10,11}$ A number of approaches have focused on modifications and/or substitutions on the base, ${ }^{12,13}$ carbohydrate ${ }^{14-19}$ and linear triphosphate moieties ${ }^{20-25}$ to design modified nucleotides for diverse applications in nucleic acid and antiviral research.

We have previously reported the synthesis of nucleoside 5 '- $O$ - $\alpha, \beta$-methylene- $\beta$ triphosphates and $5^{\prime}-O-\beta, \gamma-$ methylenetriphosphates and their potency towards the enzymatic function of wild-type HIV-1 RT. ${ }^{26,27}$ In continuation of our efforts to design a diverse array of modified nucleoside triphosphates as RT inhibitors, we herein report the synthesis of nucleoside $\beta$-triphosphate analogs (1-4) of adenosine and NRTIs, such as 3'-azido-3'deoxythymidine (zidovudine, AZT), 3'-fluoro-3'-deoxythymidine (alovudine, FLT), and 2', 3'-didehydro-2',3'-dideoxythymidine (stavudine, d4T) (Fig. 1) and their inhibitory activity against the DNA polymerase of wild-type and multidrug resistant RTs. To the best of our knowledge, this is the first report of the evaluation of nucleoside $\beta$-triphosphate analogs as RT inhibitors.

The synthesis of a $\beta$-triphosphitylating reagent from phosphorus trichloride has been previously reported by us in multi-step reactions. ${ }^{28}$ The reaction mixture containing $\beta$ triphosphitylating reagent was immediately used in coupling reactions with polymer-bound $N$-Boc $p$-acetoxybenzyl alcohol for the synthesis of a number of nucleoside $\beta$ triphosphates. ${ }^{28}$ Our research on the solid-phase synthesis of organophosphorus and organosulfur compounds revealed that the polymer-bound $p$-acetoxybenzyl alcohol containing amide linker (5) was more stable than polymer-bound $N$-Boc $p$-acetoxybenzyl alcohol even in basic conditions and was used to generate sulfonamides and other organophosphorus compounds in high yields and without the need for extensive purifications of final products. ${ }^{29,30}$ Thus, polymer-bound linker $\mathbf{5}$ instead of polymer-bound $N$-Boc $p$-acetoxybenzyl alcohol was selected for the reaction with $\beta$-triphosphitylating reagent 6 to generate a new polymer-bound $\beta$-triphosphitylating reagent 7 that was used for preparation of nucleoside $\beta$-triphosphates including two novel compounds 3 and $\mathbf{4}$ (Scheme $1)$.

Scheme 1 shows the synthesis of nucleoside 5'-O- $\beta$-triphosphates (1-4). The aminomethyl polystyrene resin-bound $p$-acetoxybenzyl alcohol $(5,3.85 \mathrm{~g}, 0.65 \mathrm{mmol} / \mathrm{g})$ was subjected to reaction with the $\beta$-triphosphitylating reagent $(6, \sim 10 \mathrm{mmol})$ in the presence of triethylamine 
(10 mmol) to produce the corresponding polymer-bound $\beta$-triphosphitylating reagent 7 . Unprotected nucleosides (e.g., adenosine (a), AZT (b), FLT (c), and d4T (d) were reacted with polymer-bound reagent $\mathbf{7}$ in the presence of 5-(ethylthio)- $1 H$-tetrazole to yield $\mathbf{8 a - d}$. Oxidation with $t$-butyl hydroperoxide followed by removal of the cyanoethoxy group with DBU, afforded the corresponding polymer-bound nucleoside 5 '- $O$ - $\beta$-triphosphotriesters (10a-d). The cleavage of polymer-bound compounds was carried out under acidic conditions (TFA). The linker-trapped resin (12) was separated from the final products by filtration. The crude products had a purity of $87-93 \%$ (Table 1) and were purified by using small $\mathrm{C}_{18}$ Sep-Pak cartridges and appropriate solvents to afford nucleoside $5^{\prime}-O-\beta$ triphosphates (1-4) in 76-90\% overall yield (calculated from polymer-bound reagent $\mathbf{7}$ in the four-step reaction sequence) (Table 1). Only one type of monosubstituted compound was produced with high selectivity as a result of this sequence possibly because of the rigidity of polymer-bound $\beta$-triphosphitylating reagent 7 . In case of adenosine, the most reactive hydroxyl group of unprotected nucleoside reacted selectively with hindered polymer-bound reagent 7 when an excess of nucleoside was used. The chemical structures of the final products (1-4) were determined by nuclear magnetic resonance spectra $\left({ }^{1} \mathrm{H} \mathrm{NMR},{ }^{13} \mathrm{C}\right.$ $\mathrm{NMR}$, and ${ }^{31} \mathrm{P}$ NMR), high-resolution time-of-flight electrospray mass spectrometry, and quantitative phosphorus analysis.

Enzyme p66/p51 HIV-1 RT was purified according to the protocol described by Le Grice $e t$ $a l .{ }^{31}$ DNA-synthesis was measured on $40 \mathrm{nt}$ DNA template annealed to a $5^{\prime}$ end-labeled 22 nt DNA primer as described previously. ${ }^{32}$

The inhibitory effects of nucleoside $\beta$-triphosphate analogs 1-4 were evaluated against the DNA polymerase activity of wild-type HIV-1 RT. The results of the inhibition assay are presented in Fig. 2. Lane W represents the DNA polymerase activity of wild type HIV-1 RT in the absence of any inhibitor, where the ${ }^{32} \mathrm{P}$-radiolabeled DNA primer was fully extended to $\mathrm{P}+10$. In the presence of the compounds $\mathbf{1 - 4}$, the DNA polymerase activity of HIV-1 RT is greatly inhibited as reflected by the absence or reduced levels of $\mathrm{P}+10$ bands (Fig. 2 panels A-D, lanes 1-6). $\beta$-Triphosphate analogs of adenosine (1) and AZT (2) completely inhibited the DNA polymerase activity at $10 \mathrm{nM}$ concentration (Fig. 2A and 1B, lane 1). With $\beta$-triphosphate analogs of FLT (3) and d4T (4), DNA synthesis was severely reduced at 10-100 $\mu \mathrm{M}$, but complete inhibition was not achieved at $1 \mathrm{mM}$ concentration (Fig. $2 \mathrm{C}$ and $\mathrm{D}$, lanes 6). These data indicate that $\beta$-triphosphate analogs of adenosine and AZT are potent inhibitors of wild-type HIV-1 RT. However, FLT and d4T analogs exhibit modest inhibitory activity against HIV-1 RT. Thus, in addition to the modified triphosphate moiety, the nature of nucleoside base is also significantly to optimal DNA polymerase inhibitory activity of wild type RT.

Subsequently, we examined to determine whether these analogs have the ability to inhibit NRTI resistant HIV-1 RT. To assess their inhibitory effects, we used the M184V/K65R/ Y115F RT. M184V confers high level resistance to lamivudine (3TC) and emtricitabine (FTC), whereas the double mutant M184V/Y115F RT has decreased susceptibility to the guanosine analogue, abacavir (ABC). ${ }^{33}$ Furthermore, K65R is associated with decreased susceptibility to tenofovir (TFV). The results of DNA polymerase assays are presented in Fig. 3. Lane W represents the DNA polymerase activity of M184V/K65R/Y115F RT in the absence of any inhibitor. With compounds 1 and 2, a complete inhibition of M184V/K65R/ Y115F RT was achieved at $10 \mu \mathrm{M}$ (Fig. 3 A-B, lane 4), although both compounds inhibited wild-type HIV-1 RT at $10 \mathrm{nM}$ concentrations (Fig. 2A-B). Surprisingly, compounds 3 and $\mathbf{4}$ completely inhibited the DNA polymerase activity of this enzyme at $100 \mu \mathrm{M}$ (Fig. 3C and 3D, lane 5), even though they did not show similar potency against wild-type HIV-1 RT. 
The potency of these analogues against NNRTI resistant HIV-1 RT was also examined. NNRTIs bind in a non-competitive manner to a specific pocket of the HIV-1 RT, which is closely associated with, but distinct from, the substrate binding site. In our studies, we used HIV-1 RT with Thymidine Associated Mutations (TAMs) that confer resistance to NNRTIs. ${ }^{5}$ The results of the inhibitory activities of these compounds are presented in Fig. 4. Overall the nucleoside $\beta$-triphosphate analogs (1-4) showed lower potency against NNRTI resistant RTs in comparison to NRTI resistant RTs. Compounds $\mathbf{1}$ and $\mathbf{2}$ did not inhibit DNA polymerase activity of NNRTI HIV-1 RT significantly at $10 \mathrm{nM}-10 \mu \mathrm{M}$ (Fig. 4 panels A-B, lanes 1-4). However, they completely inhibited the NNRTI resistant RT at $100 \mu \mathrm{M}$ (Fig. 4 panels $\mathrm{A}$ and $\mathrm{B}$, lane 5). Although, compounds $\mathbf{3}$ and $\mathbf{4}$ impaired polymerase activity, complete inhibition was not achieved at concentrations up to $1 \mathrm{mM}$ (Fig. $4 \mathrm{C}$ and D, lane 6).

$\beta$-Triphosphates analogs of adenosine (1) and AZT (2) potently inhibited wild-type (10 nM) and showed modest potency towards NRTI resistant RTs $(10 \mu \mathrm{M})$ and NNRTI resistant RTs $(100 \mu \mathrm{M})$. On the other hand, compounds $\mathbf{3}$ and $\mathbf{4}$ inhibited most of DNA polymerase activity of wild-type at 10-100 $\mu \mathrm{M}$, but complete inhibition was not achieved at $1 \mathrm{mM}$, suggesting that in addition to the $\beta$-triphosphate moiety, the nature of nucleotide base plays a critical role in optimal wild type DNA polymerase inhibition. Interestingly, compounds 3 and 4 exhibited better potency towards NRTI resistant RTs $(100 \mu \mathrm{M})$ when compared with wild type RT $(1 \mathrm{mM})$, indicating that the presence of a $\beta$-triphosphate moiety and the nature of the base contribute to the inhibition of NRTI resistant RTs.

In case of NRTIs, drug resistance affects the binding and rate of incorporation of the incoming nucleotide analog and primarily involves residues in direct contact with the incoming NRTI triphosphate. These residues include K65R, L74V, Y115F, M184V/I, and Q151M that cause steric hindrance to the proper binding of these inhibitors in the HIV RT active site. ${ }^{34}$ In contrast, NNRTI resistant mutations (TAMs) in HIV-1 RT are located in the allosteric site residues that prevent binding of the inhibitors. We assume that these nucleoside $\beta$-triphosphate analogs have the ability to compete with the dNTP binding site of HIV-1 RT, thereby conferring potent inhibitory activity against NRTI resistant RTs. However, the potency of these analogs is limited towards the NNRTI resistant RT, indicating that they cannot effectively bind to the allosteric site of the RT.

Our data revealed that, $\beta$-triphosphate analogs of adenosine and AZT were highly potent against the wild-type and NRTI/NNRTI resistant RTs in comparison to the FLT and d4T analogs. Thus, these analogs could potentially serve as lead molecules for designing inhibitors that can inhibit an array of drug resistant HIV-1 RTs. Further investigations are underway to determine the exact mechanism of inhibition of polymerase activity of wild type and NRTI resistant HIV-1 resistant RT.

\section{Supplementary Material}

Refer to Web version on PubMed Central for supplementary material.

\section{Acknowledgments}

K. P. acknowledges the National Science Foundation, Grant Number CHE 0748555 for the financial support and National Center for Research Resources, NIH, and Grant Number 1 P20 RR16457 for sponsoring the core facility. C. D. acknowledges NIH Grant \# R00DA024558, and R03DA30896 and Faculty start up funds from VanderbiltMeharry CFAR. 


\section{References}

1. Telesnitsky, A.; Goff, SP. Retroviruses. Coffin, JM.; Hughes, SH.; Varmus, HE., editors. Cold Spring Harbor Laboratory Press; Plainview, New York: 1997. p. 121

2. Le Grice, SF. Reverse transcriptase. Skalka, AM.; Goff, S., editors. Cold Spring Harbor Laboratory Press; Plainview, New York: 1993. p. 163

3. Klumpp K, Mirzadegan T. Curr Pharm Des. 2006; 12:1909. [PubMed: 16724956]

4. De Clercq E. Biochimica et Biophysica Acta. 2002; 1587:258. [PubMed: 12084468]

5. Cihlara T, Ray AS. Antiviral Res. 2010; 85:39. [PubMed: 19887088]

6. Prajapati DG, Ramajayam R, Yadav MR, Giridhar R. Bioorg Med Chem. 2009; 17:5744. [PubMed: 19632850]

7. Menéndez-Arias L. TRENDS in Pharmacol Sci. 2002:23.

8. Spelta V, Mekhalfia A, Rejman D, Thompson M, Blackburn GM, North RA. J Pharmacol. 2003; 140:1027.

9. Wang G, Boyle N, Chen F, Rajappan V, Fagan P, Brooks JL, Hurd T, Leeds JM, Rajwanshi VK, Jin Y, Prhavc M, Bruice TW, Cook PD. J Med Chem. 2004; 47:6902. [PubMed: 15615539]

10. Arabshahi L, Khan NN, Butler M, Noonan T, Brown NC, Wright GE. Biochem. 1990; 29:6820. [PubMed: 2118802]

11. Ono K, Nakane H, Herdewijn P, Balzarini J, De Clercq E. Mol Pharmacol. 1989; 35:578. [PubMed: 2471054]

12. Kawate T, Allerson CR, Wolfe JL. Org Lett. 2005; 7:3865. [PubMed: 16119918]

13. Hoffmann C, Genieser HG, Veron M, Jastorff B. Bioorg Med Chem Lett. 1996; 6:2571.

14. Wu W, Meyers CLF, Borch RF. Org Lett. 2004; 6:2257. [PubMed: 15200334]

15. Camplo M, Faury P, Charvet AS, Graciet JC, Chermann JC, Kraus JL. Eur J Med Chem. 1994; 29:357.

16. Chong Y, Gumina G, Mathew JS, Schinazi RF, Chu CK. J Med Chem. 2003; 46:3245. [PubMed: 12852755]

17. von Janta-Lipinski M, Costisella B, Ochs H, Hubscher U, Hafkemeyer P, Matthes E. J Med Chem. 1998; 41:2040. [PubMed: 9622545]

18. Anastasi C, Quelever G, Burlet S, Garino C, Souard F, Kraus JL. Curr Med Chem. 2003; 10:1825. [PubMed: 12871107]

19. Van Aerschot A, Herdewijn P, Balzarini J, Pauwels R, De Clercq E. J Med Chem. 1989; 32:1743. [PubMed: 2754700]

20. Okruszek A, Olesiak M, Balzarini J. J Med Chem. 1994; 37:3850. [PubMed: 7525960]

21. Barai VN, Zinchenko AI, Kvach SV, Titovich OI, Rubinova EB, Kalinichenko EN, Mikhailopulo IA. Helv Chim Acta. 2003; 86:2827.

22. Ludwig J, Eckstein F. Nucleosides \& Nucleotides. 1991; 10:663.

23. Ludwig J, Eckstein F. J Org Chem. 1991; 56:5860.

24. Ludwig J, Eckstein F. J Org Chem. 1991; 56:1777.

25. Ma QF, Bathurst IC, Barr PJ, Kenyon GL. J Med Chem. 1992; 35:1938. [PubMed: 1375962]

26. Ahmadibeni Y, Dash C, Le Grice S, Parang K. Tet Lett. 2010; 51:3010.

27. Ahmadibeni Y, Dash C, Hanley MJ, Le Grice S, Agarwal HK, Parang K. Org Biomol Chem. 2010; 8:1271. [PubMed: 20204192]

28. Ahmadibeni Y, Parang K. J Org Chem. 2006; 71:5837. [PubMed: 16839180]

29. Kumar A, Ye G, Ahmadibeni Y, Parang K. J Org Chem. 2006; 71:7915. [PubMed: 16995713]

30. Ahmadibeni Y, Parang K. Org Lett. 2007; 9:4483. [PubMed: 17915884]

31. Le Grice SF, Cameron CE, Benkovic SJ. Methods Enzymol. 1995; 262:130. [PubMed: 8594344]

32. Dash C, Fisher TR, Prasad VR, Le Grice S. J Biol Chem. 2006; 281:27873. Reactions were initiated in the presence or absence of the compounds by adding $10 \mathrm{nM}$ enzyme to a mixture containing $50 \mathrm{nM}$ template/primer, dNTPs $(200 \mu \mathrm{M})$, Tris- $\mathrm{HCl}(10 \mathrm{mM}, \mathrm{pH} 8.0), \mathrm{NaCl}(80 \mathrm{mM})$, and $\mathrm{MgCl}_{2}(6 \mathrm{mM})$, and terminated after $10 \mathrm{~min}$ by adding an equal volume of a formamide-based gel-loading buffer at $37{ }^{\circ} \mathrm{C}$. Reaction products were fractionated by high-voltage electrophoresis 
through $10 \%(\mathrm{w} / \mathrm{v})$ polyacrylamide gels containing $7 \mathrm{M}$ urea in Tris/borate/EDTA buffer. After drying, gels were subjected to autoradiography and/or phosphorimaging analysis using a Molecular Imager FX phosphorimager. [PubMed: 16867979]

33. Ehteshami M, Scarth BJ, Tchesnokov EP, Dash C, Le Grice SF, Hallenberger S, Jochmans D, Götte M. J Biol Chem. 2008; 283:29904. [PubMed: 18728003]

34. Sarafianos SG, Das K, Clark AD Jr, Ding J, Boyer PL, Hughes SH, Arnold E. Proc Nat Acad Sci USA. 1999; 96:10027. [PubMed: 10468556] 
<smiles>Cc1cn(C2C[C@@H](N)[C@]3(COP(=O)(OP(=O)(O)O)OP(=O)(O)O)O[C@@H]2C[C@@H]3O)c(=O)[nH]c1=O</smiles><smiles>Cc1cn(C23C=C[C@@H](COP(=O)(OP(=O)(O)O)OP(=O)(O)O)O[C@@H]2C[C@H](F)[C@H]3COP(=O)(OP(=O)(O)O)OP(=O)(O)O)c(=O)[nH]c1=O</smiles>

Figure 1.

Chemical structures of nucleoside 5'-O- $\beta$-triphosphates (1-4). 


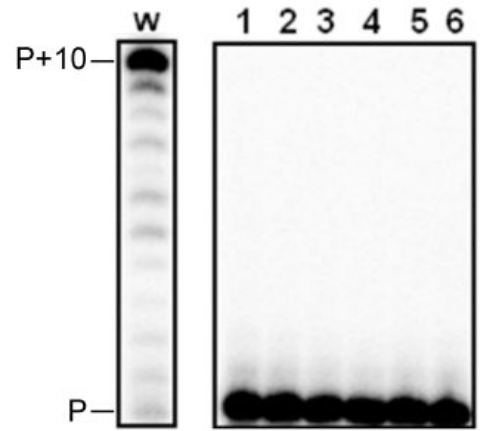

(A) Compound 1

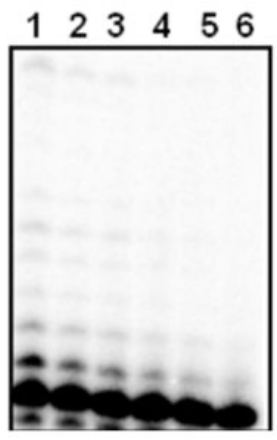

(B) Compound 2

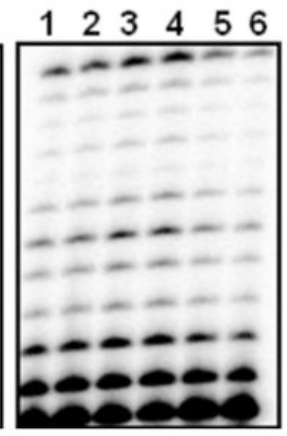

(C) Compound 3

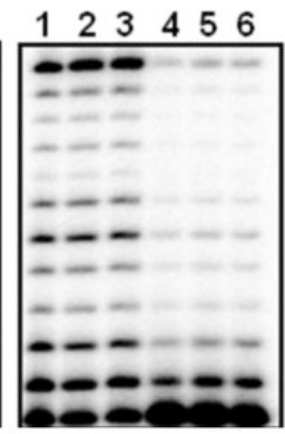

(D) Compound 4

Figure 2.

DNA polymerase activity of HIV-1 RT. The ${ }^{32} \mathrm{P}$-radiolabeled primer is marked as $\mathrm{P}$, whereas the fully extended product is marked as $\mathrm{P}+10$. Lane $\mathrm{W}$ represents DNA polymerase activity in the absence of any inhibitor. DNA polymerase activities in presence of inhibitors are presented in Panel A (compound 1), B (compound 2), C (compound 3), and D (compound 4). Lane $1(10 \mathrm{nM})$, lane $2(100 \mathrm{nM})$, lane $3(1 \mu \mathrm{M})$, lane $4(10 \mu \mathrm{M})$, lane $5(100$ $\mu \mathrm{M})$, and lane $6(1 \mathrm{mM})$. 


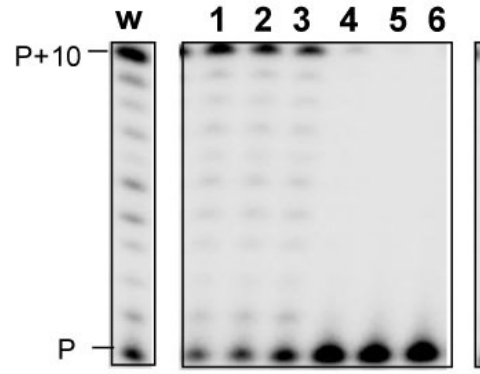

(A) Compound 1

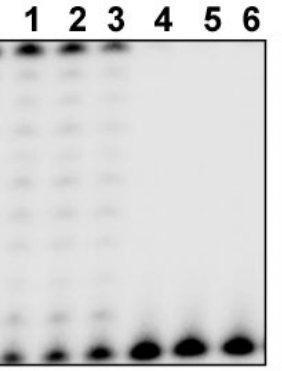

(B) Compound 2

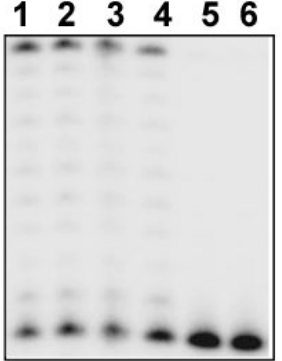

(C) Compound 3

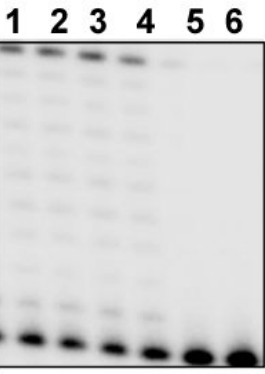

(D) Compound 4

Figure 3.

DNA polymerase activity of NRTI resistant HIV-1 RT mutant M184V/K65R/Y115F.

The ${ }^{32} \mathrm{P}$-radiolabeled primer is marked as $\mathrm{P}$, whereas the fully extended product is marked as $\mathrm{P}+10$. Lane $\mathrm{W}$ represents DNA polymerase activity in the absence of any inhibitor. DNA polymerase activities in presence of inhibitors are presented in Panel A (compound 1), B (compound 2), C (compound 3), and D (compound 4). Lane 1 (10 nM), lane 2 (100 nM), lane $3(1 \mu \mathrm{M})$, lane $4(10 \mu \mathrm{M})$, lane $5(100 \mu \mathrm{M})$, and lane $6(1 \mathrm{mM})$. 


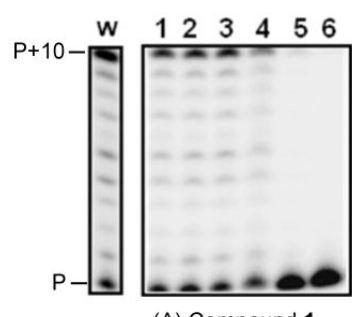

(A) Compound 1

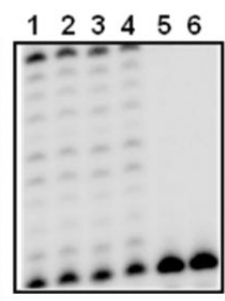

(B) Compound 2

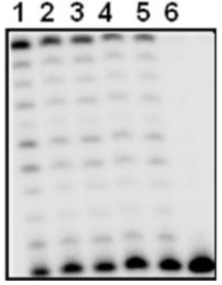

(C) Compound 3

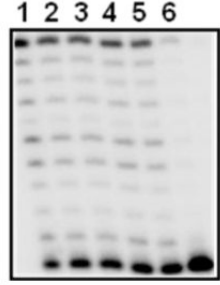

(D) Compound 4

Figure 4.

DNA polymerase activity of NNRTI Resistant HIV-1 RT. The ${ }^{32} \mathrm{P}$-radiolabeled primer is marked as $\mathrm{P}$, whereas the fully extended product is marked as $\mathrm{P}+10$. Lane $\mathrm{W}$ represents DNA polymerase activity in the absence of any inhibitor. DNA polymerase activities in presence of inhibitors are presented in Panel A (compound 1), B (compound 2), C (compound 3), and D (compound 4). Lane $1(10 \mathrm{nM})$, lane $2(100 \mathrm{nM})$, lane $3(1 \mu \mathrm{M})$, lane 4 $(10 \mu \mathrm{M})$, lane $5(100 \mu \mathrm{M})$, and lane $6(1 \mathrm{mM})$. 

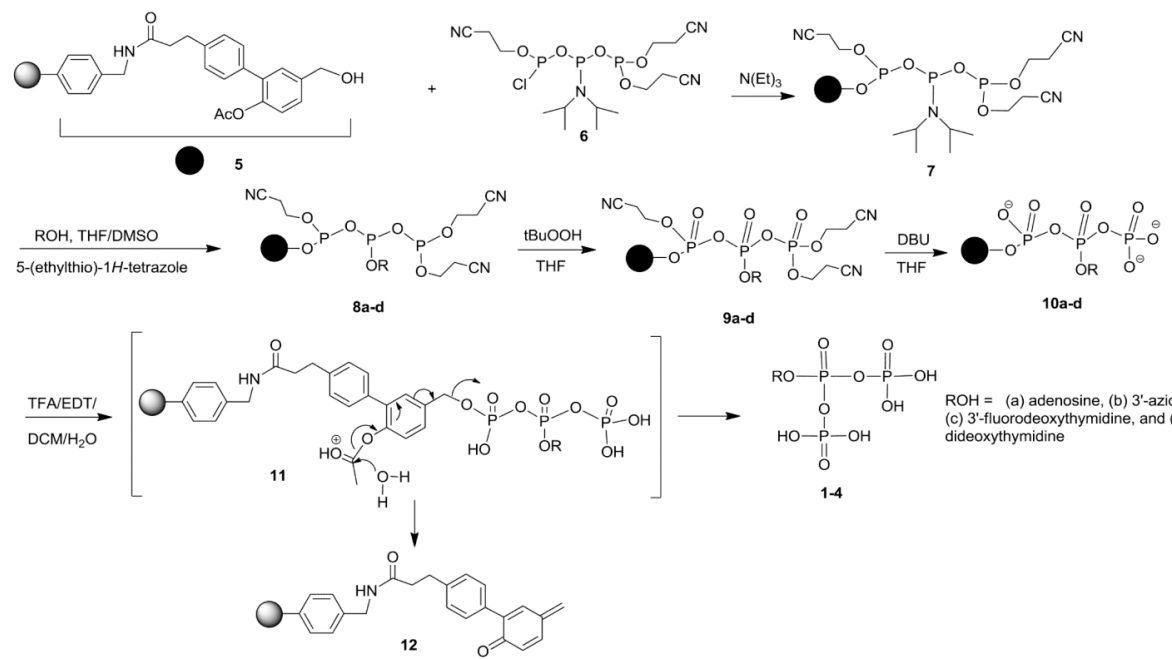

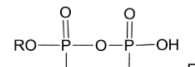

$\mathrm{ROH}=$ (a) adenosine, (b) 3'-azido-3'-deoxythymidine,
(c) 3'-fluorodeoxythymidine, and (d) $2^{\prime} 3^{\prime}-$ didehydro-2'

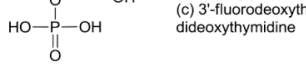

Scheme 1.

Synthesis of polymer-bound $\beta$-triphosphitylating reagent 7 and nucleoside 5 ' $-O$ - $\beta$ triphosphates 1-4 using polymer-bound linker $\mathbf{5}$. 


\section{Table 1}

Overall isolated yields and purity of crude products for nucleoside $5^{\prime}-O$ - $\beta$-triphosphates (1-4).

\begin{tabular}{ccc}
\hline Compound & Overall yield (\%) calculated from $\mathbf{7}$ & Purity of crude products (\%) \\
\hline $\mathbf{1}$ & 82 & 87 \\
$\mathbf{2}$ & 90 & 93 \\
$\mathbf{3}$ & 85 & 91 \\
$\mathbf{4}$ & 76 & 88 \\
\hline
\end{tabular}

